\title{
水圧と面内圧縮荷重を受ける連続防撓パネルの 最終強度推定法
}

\author{
正員 柳原 大輔 $*$ 正員 藤久保昌 彦 * \\ 森田 竜太郎 $* *$ 瀬戸山 雄 $*$
}

Estimation of Ultimate Strength of Continuous Stiffened Plate under
Combined Thrust and Lateral Pressure

by Daisuke Yanagihara, Member Ryutaro Morita

Masahiko Fujikubo, Member Yuu Setoyama

\section{Summary}

A series of elastoplastic large deflection analyses is performed by FEM in order to clarify the buckling/plastic collapse behaviour of stiffened plates subjected to combined longitudinal thrust and lateral pressure on the plate side. Double span/double bay or triple span/double bay models are employed to consider the plate continuity. It has been found that the continuous stiffened plates have three collapse modes, which are Stiffener-Induced failure caused by stiffener yielding, Plate-Induced failure by local plate collapse and Hinge-Induced failure by the formation of plastic hinges predominantly in bending. Based on the collapse behaviour observed by FEM, a simplified method to estimate the ultimate strength of the stiffened plates under combined thrust and lateral pressure is developed. Through the comparison of the estimated ultimate strength with the FEM results, the validity and usefulness of the proposed method are demonstrated.

1. 緒言

船体構造はロンジ材やフロア材で補強された防撓パネル 構造となっている。ホギング状態の船体を考えた場合, 船底 外板を構成する防撓パネルには縦曲げによる船長方向の面 内圧縮荷重と，水圧による横分布荷重が作用する。船底外 板の座屈崩壊は船体構造全体の崩壊に直結するため, 面内 圧縮荷重と水圧荷重を同時に受ける防撓パネルの座屈・塑 性崩壊強度の検討が重要になる。

ロンジ材とトランス材位置で支持された連続パネルを考 えた場合, 水圧荷重が作用すると隣接パネルは同じ方向へ

* 広島大学大学院工学研究科

** コマツ (研究当時 広島大学大学院工学研究科)

原稿受理 平成 14 年 7 月 10 日

秋季講演会において講演 平成 14 年 11 月 14,15 日
たわもうとし，面内圧縮荷重のもとでのパネルの座屈モー ドの発生に抵抗する。一方で水圧によって発生するたわみ は面内に引張り膜力を発生させる。したがって水圧荷重の もとでの弾性座屈強度は上昇する ${ }^{1,2)}$ 。また, 水圧荷重が 比較的小さい場合, 弾性座屈応力の上昇にともない圧縮最 終強度も上昇するが，さらに水圧荷重が大きくなると，パ ネルは周辺固定の崩壊モードを形成し，水圧上昇とともに 最終強度は低下していく。著者らの一人はこのよう座屈・塑 性崩壊挙動を考慮して, 水圧荷重と面内圧縮荷重を受ける 連続パネルの弾性座屈強度算式 2,3) ならびに最終強度算式 4,5) を導いている。

以上のように, 水圧と面内圧縮荷重を受ける連続パネル については，その圧壊挙動に対する知見は十分に得られて いると言える。しかしながら，実際の構造では，パネルは ロンジ材で支持されており, 連続パネルとしての最終強度 に達する前にロンジ材が崩壊する可能性もある。したがっ て，防掕パネルとしての検討が不可欠である。 
防撓パネルを対象とした研究として例えば，Smith ${ }^{6)}$ は, 連続防撓パネルに水圧とロンジ方向の面内圧縮荷重を負荷 する座屈試験を実施している。また, Wang 7) らは, FEM 解析を実施し，水圧を考慮した連続防撓パネルの座屈・塑 性崩壊挙動を調べると同時に, 後述の DNV 強度算式の検 証を行っている。このように，水圧と面内圧縮荷重を受け る防撓パネルを対象とした幾つかの研究があるもの, 連続 パネルに比べその数は少なく，圧壊挙動に対する知見は十 分に得られているとは言い難い状況にある。

一方, $\mathrm{DNV}^{8)}$ は, 水圧と面内圧縮荷重を受ける防撓パ ネルの最終強度算式を提案している。この算式では，防撓 パネルをパネルの座屈後の有効幅をフランジとして有する 1 本の梁・柱にモデル化し，Fig. 1 に示すような, パネルが 曲げの圧縮側となる Plate-induced failure (PI 崩壊) と, 防撓材が曲げの圧縮側となる Stiffener-induced failure (SI 崩壊) に分類している。そして，それぞれの崩壊モードに 対して Perry-Robertson 式を適用して圧縮最終強度を算出 し，両者のうち低い方を真の最終強度としている。このう ち水圧荷重の影響は, PI 崩壊のみに考慮されている。

ところで, 著者らは面内圧縮荷重のみが作用する連続防

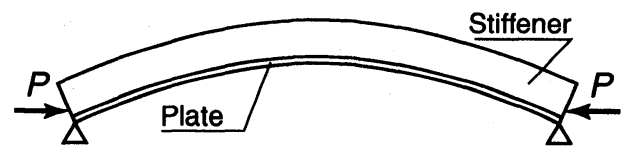

(a) Plate-induced failure

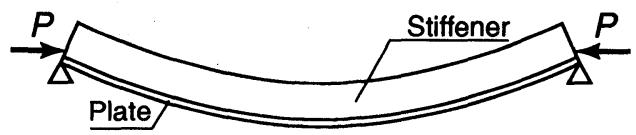

(b) Stiffener-induced failure

Fig. 1 Failure modes of stiffened plates

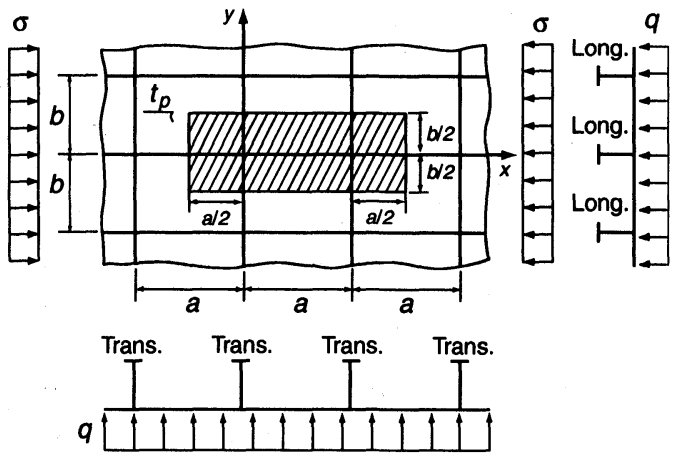

Fig. 2 Continuous stiffened plate under combined longitudinal thrust and lateral pressure
撓パネルを対象として, 簡易最終強度推定法を開発してい る 9,10)。この方法では，上述の DNV 算式と同様に，防 撓パネルを 1 本の梁・柱にモデル化し, Perry-Robertoson 式を適用して最終強度を推定している。ただし，パネルの 連続性の影響を考虑するためダブルスパンの領域をモデル 化するとともに，面外変形に対するパネルと防撓材間の相 間関係が考虑されている。この簡易算式は非常に高い精度 で最終強度を推定することができる。

本研究では, 連続防撓パネルにパネル側からの水圧荷重 と防撓材方向の面内圧縮荷重が作用する場合について，有 限要素法による弾塑性大たわみ解析を実施し，水圧荷重が 連続防撓パネルの圧壊挙動に及ほす影響について考察を行 う。次に，得られた知見に基づき，著者らが開発した上述 の簡易最終強度推定法に水圧の影響を導入し，水圧と面内 圧縮荷重を受ける連続防撓パネルの最終強度推定法を提案 する。最後に, FEMによる解析結果と比較を通して提案手 法の精度を検証する。

\section{2. 水圧と面内圧縮荷重を受ける連続防撓パネルの 圧壊挙動}

\section{1 解析対象と解析方法}

Fig. 2 に示すようにパネル側からの水圧荷重と，防撓材 方向に 1 軸圧縮荷重を同時に受ける連続防撓パネルを対象 として，FEM による弾塑性大たわみ解析を実施する。防撓 材形状は, flat-bar, angle-bar および tee-bar の 3 種類と し，それぞれ Table 1 に示す 3 つの形状を考える。防撓材 間のパネル寸法は $a \times b=2,400 \times 800 \mathrm{~mm}$ とし, パネル板 厚は $t_{p}=10,13,15,20,25 \mathrm{~mm}$ の 5 種類とする。材料定 数はパネル・防撓材ともにヤング率 $E=205 \mathrm{GPa}$ ，降伏強度 $\sigma_{Y}=313 \mathrm{MPa}$ とし，降伏後のひずみ硬化は無視する。

Table 1 Dimensions of stiffeners

\begin{tabular}{|c|c|c|c|}
\hline & type 1 & type 2 & type 3 \\
\hline flat-bar & $150 \times 17$ & $250 \times 19$ & $350 \times 35$ \\
\hline angle-bar & $150 \times 90 \times 9 / 12$ & $250 \times 90 \times 10 / 15$ & $400 \times 100 \times 12 / 17$ \\
\hline tee-bar & $150 \times 9+90 \times 12$ & $250 \times 10+90 \times 15$ & $400 \times 12+100 \times 17$ \\
\hline
\end{tabular}

$\begin{array}{ll}\text { flat-bar } & : h \times t_{w}(\mathrm{~mm}) \\ \text { angle-bar } & : h \times b_{f} \times t_{w} / t_{f}(\mathrm{~mm}) \\ \text { tee-bar } & : h \times t_{w}+b_{f} \times t_{f}(\mathrm{~mm})\end{array}$

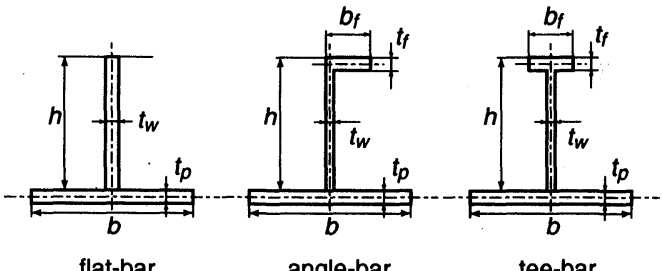

flat-bar 
解析範囲として, Fig. 2 の網掛けで示すトリプルスパン/ ダブルベイの領域を考え，パネルとロンジ材をシェル要素で モデル化する。トランス材に関してはモデル化はしないもの の，この位置でパネルのたわみを拘束する。なお, angle-bar 防撓材が取り付けられている場合には，非対称断面の影響 を考慮して，トリプルスパン/トリプルベイの範囲をモデル 化する 11)。

水圧荷重は防撓材を挟んで隣接パネルを同方向にたわま せるため，防撓材位置での境界条件は固定条件へと近づく。 したがって，水圧を考慮した弾性座屈半波数は，水圧荷重 がない場合の座屈半波数に比べ，より高次モードへと変化 する場合がある 12)。そこで，複数の初期たわみ成分を足し 合わせた次式で与えられる防撓材間のパネルの初期たわみ $w_{0 p}$ を考える。

$$
w_{0 p}=\sum_{m=3}^{7} A_{0 m} \sin \frac{m \pi x}{a} \sin \frac{\pi y}{b}
$$

初期たわみ係数 $A_{0 m}$ はいずれの成分においてもパネル 板厚 $t_{p}$ の $0.5 \%$ とする。一方，防撓材の初期たわみとし て, Euler 座屈モードの初期たわみを考え, その最大值を $w_{0 \max }=0.001 a$ とする。また, 初期据れ変形は, 防撓材頂 部の水平たわみの最大值が $0.001 a$ となるように与える。な お，本論文では溶接残留応力の影響は無視する。

解析に当たっては，まず水圧荷重を所定の大きさまで作 用させた後に，防撓材方向に面内圧縮荷重を変位制御で増 分的に与えた。水圧荷重はパネル側から常にパネル面に垂 直になるように作用させ，水頭換算で 0〜35m の範囲で変

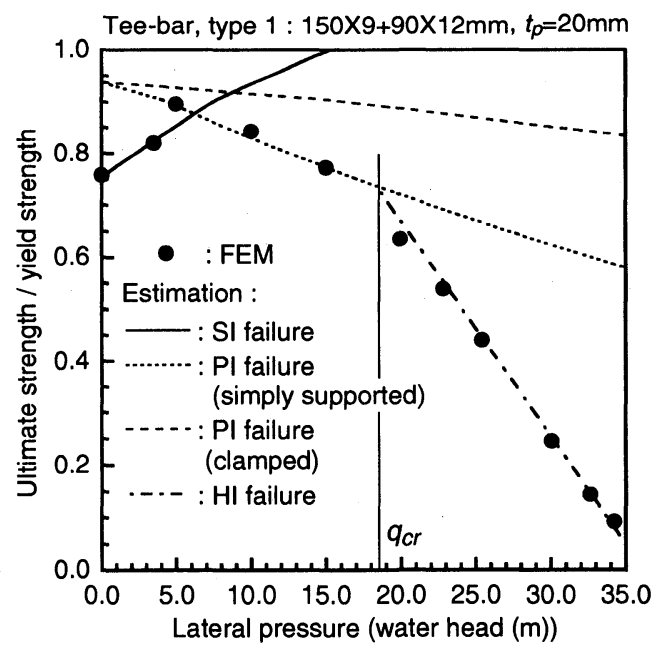

Fig. 3 Relationships between compressive ultimate strength and lateral pressure obtained by FEM and proposed method
化させた。解析コードとして，広島大学で開発された弾塑 性大たわみ有限要素法コード ULSAS を使用した。

\section{2 解析結果}

Fig. 3 は, 板厚 $20 \mathrm{~mm}$ のパネルに type 1 の比較的高さ の低い tee-bar 防撓材が取り付けられた場合の水圧荷重と 圧縮最終強度の関係を表している。縦軸の最終強度は降伏 強度で無次元化し, 横軸の水圧は水頭換算で表している。図 中の○が FEM による解析結果を表している。また, Fig. 4 は圧縮荷重が最終強度に達した時点の変形と降伏域の拡 がりを示している。困は上から見た全体の鳥瞰図と側面図 の両者を示し, 要素内の色の濃淡が板厚方向の降伏域の拡 がりを示している。

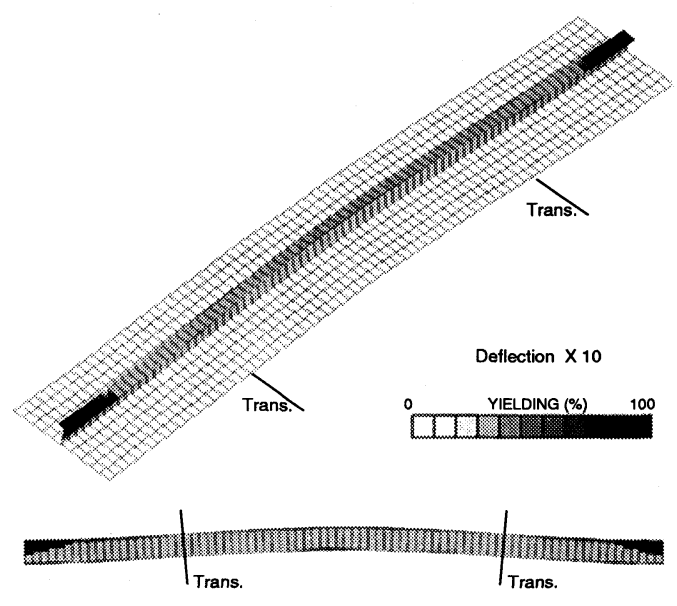

(a) $q=0 \mathrm{~m}$ water head

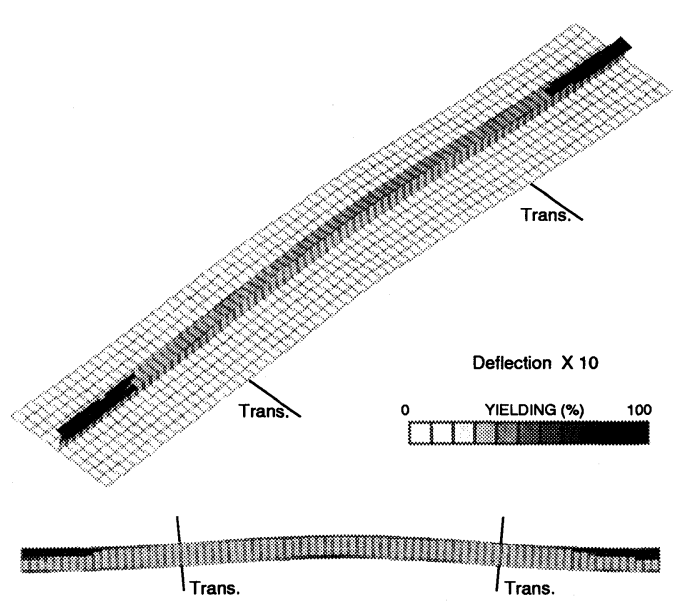

(b) $q=3.5 \mathrm{~m}$ water head

Fig. 4 Deflection mode and spread of yielding zone at ultimate strength (tee-bar, type $1, t_{p}=20 \mathrm{~mm}$ ) 


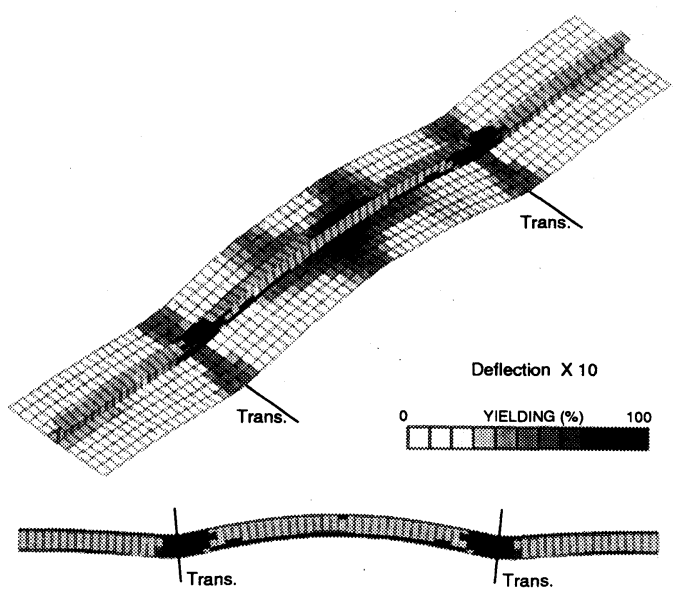

(c) $q=15 \mathrm{~m}$ water head

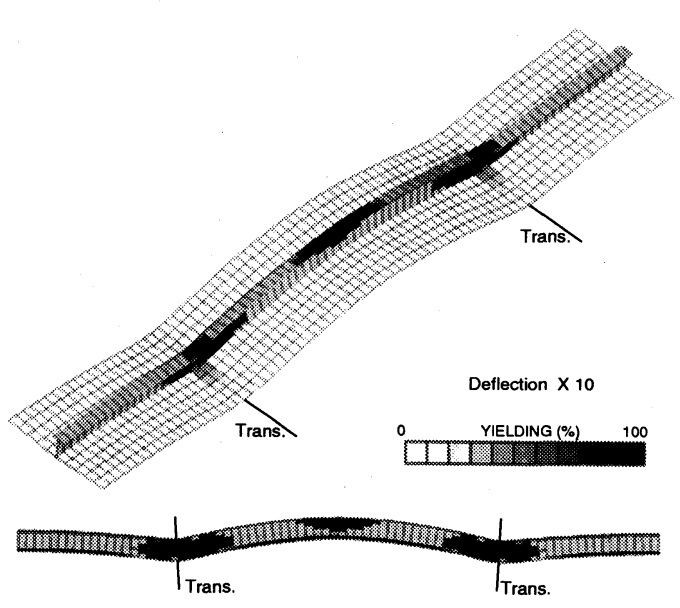

(d) $q=30 \mathrm{~m}$ water head

Fig. 4 Deflection mode and spread of yielding zone at ultimate strength (tee-bar, type $1, t_{p}=20 \mathrm{~mm}$ ) (continued)

Fig. 4(a) に示す水圧荷重が水頭換算で $0 \mathrm{~m}$ の場合, Euler 座屈モードの変形が成長して最終強度に達しているのがわ かる。この時, 防撓材が曲げの圧縮側となるモデル端部で は防撓材頂部に降伏域が拡がり，これが最終強度を決める 要因となっている。このことから水圧荷重がない場合の崩 壊モードは DNVにおける SI 崩壊となっていることがわ かる。

Fig. 4(b) に示す水圧荷重が水頭換算で $3.5 \mathrm{~m}$ となる場 合, Fig. 4(a) の場合と同様に最終強度時には Euler 座屈 モードの変形が成長し，防撓材が曲げの圧縮側となる防撓 材頂部で降伏が搪がっている。この場合も SI 崩壊モードと 見なすことができる。一方，Fig. 3 を見ると，水圧が $3.5 \mathrm{~m}$

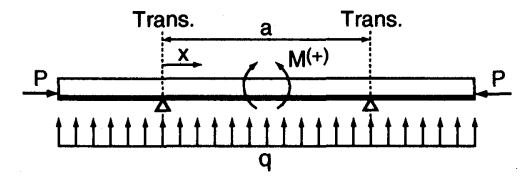

Tee-bar, type $1: 150 \times 9+90 \times 12 \mathrm{~mm}, t p=20 \mathrm{~mm}$

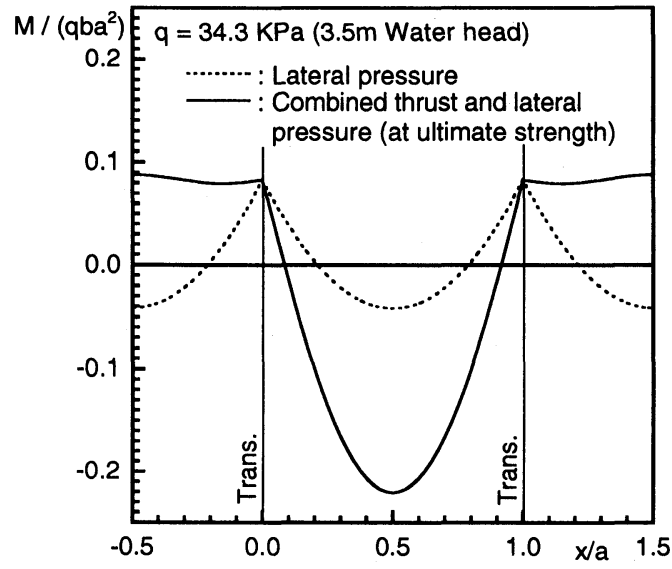

(a) $q=3.5 \mathrm{~m}$ water head

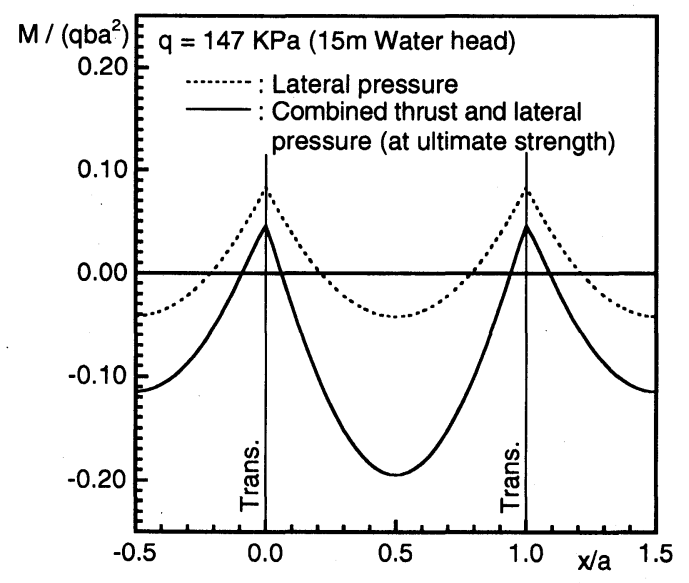

(b) $q=15 \mathrm{~m}$ water head

Fig. 5 Distributions of bending moment of stiffened plate under lateral pressure/combined thrust and lateral pressure

の場合の圧縮最終強度は水圧がない場合に比べ上昇してい る。これは, 水圧による曲げ変形が防撓材頂部の降伏を遅 らせるためであり, 水圧 $5 \mathrm{~m}$ までの範囲では, 水圧荷重の 増加とともに圧縮最終強度も上昇する。

ところで，Fig. 5(a) は水圧荷重のみが作用している状 態と, 最終強度まで圧縮荷重が増加した時点での曲げモー メント分布を示している。ここでの曲げモーメントは, 断 面を構成する各節点の軸方向節点力から平均応力に相当す 
る荷重を差し引いた荷重分布から求めている。図中の点線 で示す水圧のみが作用している状態では, 支持点であるト ランス材位置で曲げモーメントが最も大きくなり，その值 は, 梁理論で計算される両端固定梁の固定端の曲げモーメ ント $\left(M /\left(q b a^{2}\right)=1 / 12\right)$ とほほ一致している。その後, 実 線で示す最終強度まで圧縮荷重を増加させると, トランス 材位置での曲げモーメントはほとんど変化せず, 水圧のみ による曲げモーメントに, Euler モードの座屈変形が作る 曲げモーメント（解析対象中央部で值が負になる正弦波形 状）が足し合わされたような分布となっている。このよう に, 水圧荷重が小さく，その崩壊モードが SI 崩壊となる場 合では, 面内荷重が増加した後も，両端固定のもとで水圧 が作る曲げモーメント分布が保持される。

さらに高い水圧荷重のもとでは, 面内圧縮荷重の増加と ともに，はじめにトランス材位置で降伏が拡がるものの,こ の段階では圧縮耐力は上昇し，パネルが曲げ圧縮側となる スパン中央で降伏が拡がった後に最終強度に達する。Fig. 4 (c) は水頭換算で $15 \mathrm{~m}$ の水圧荷重を与えた場合の変形図 を示している。図より,トランス材位置と中央スパン中央 のパネルに降伏が拡がっていることが確認できる。この場 合は, パネルの降伏が最終強度を決める要因となっており, DNVにおける PI 崩壊に相当する。変形図をさらに詳しく 見てみると, トランス材位置で防撓材のほほ全断面が降伏 しており，また中央スパンではあたかもトランス材位置で 単純支持されたような変形が生じていることがわかる。

ここで，Fig. 5(b) の曲げモーメント分布を見てみると， 圧縮荷重が最終強度まで達すると, 曲げモーメントが 0 と

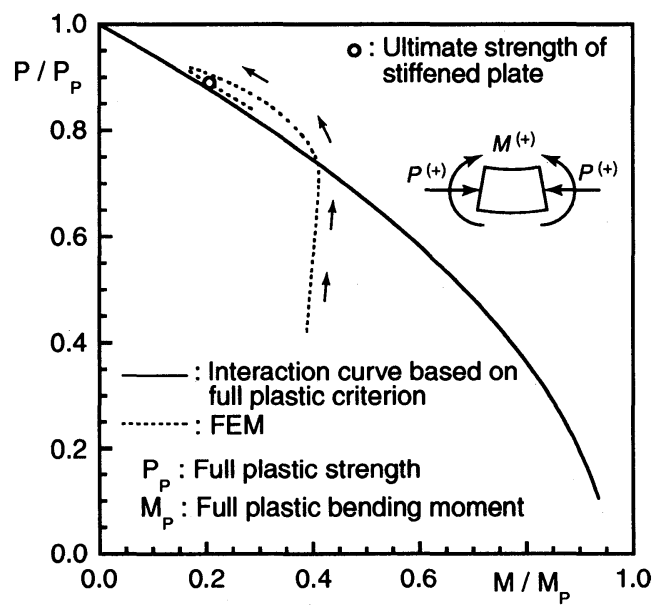

Fig. 6 Relationships between axial load and bending moment of stiffener cross-section at supported point by transverse floor (tee-bar, type $1, t_{p}=20 \mathrm{~mm}$, $q=15 \mathrm{~m}$ water head)
なる点がトランス材位置に近づく。また, トランス材位置で の曲げモーメントが減少しており, 単純支持の状態へと近 づいていることがわかる。この原因を究明するために, ト ランス材位置の防撓材断面に生じる曲げモーメントと圧縮 軸力の変化を調べた。その結果を Fig. 6 に示す。図中の実 線は全断面塑性条件を表し, 破線が FEM 解析結果を表し ている。水圧のみが作用した時点で防撓材には軸力および 曲げモーメントが生じ, 圧縮荷重の増加とともに両者とも 増加していく。その後, 実線で示す全断面塑性条件に達する と曲げモーメントは隇少し, 軸力のみが増加していく。この ことから, Fig. 5(b) に示したトランス材位置の曲げモーメ ントの隇少は, ほほ全断面降伏した防撓材断面の曲げモー メントが, 圧縮軸力の増加とともに, 全断面塑性条件上に 沿って変化することに起因していると考えられる。ところ で, 改めて Fig. 4(c) の側面図に注目すると, 隣接スパン で防撓材のたわみの大きさが異なっていおり, Euler 座屈 モードの成分が成長していることがわかる。これは, 座屈 により発生するたわみモードそのものは, 两端単純支持の 場合に近いことを表している。以上のことから, 水圧があ る程度大きくなり, 崩壊モードが PI 崩壊となる場合には, 中央スパンは両端支持梁としての挙動に近づく。また, Fig. 3 からわかるように, PI 崩壊の範囲では, 水圧の増加とと もに圧縮最終強度は減少していく。

さらに大きな水圧荷重が作用している段階では, 水圧荷 重のみで, トランス材位置で初期降伏が生じる水圧（Fig. 3 の縦線で示す $\left.q_{c r}\right)$ を超えると, Fig. 4(d) に示すように最 終強度時には, トランス材位置およびスパン中央の防撓材頂 部に降伏域が拡がる。この降伏域の集中箇所は, 水圧による 横荷重のみが作用する場合に生成される塑性関節の位置と一 致する。そこで, この崩壊モードを Plastic hinge-induced failure (HI 崩壊) と呼ぶことにする。Fig. 3 に示すよう に, HI 崩壊モードでは, 水圧が $q_{c r}$ を越えるところから,
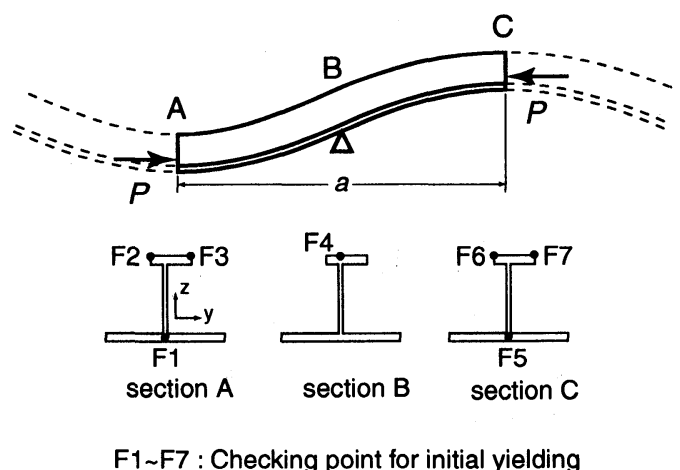

Fig. 7 Double span bream-column model and checking points for yielding 
水圧荷重の增加とともに圧縮最終強度は，ほほ線形にかつ 急激に低下していき, 最終的に, ほほ剖塑性機構解析で得 られる両端固定梁の最大横荷重 (約 $38 \mathrm{~m}$ ) で圧縮最終強度 が 0 となる点へ収束していく。

以上の解析結果より, 水圧と面内圧縮荷重を受ける連続 防撓パネルの崩壊モードは，水圧の大きさに応じて，SI 崩 壊，PI 崩壤および HI 崩壊に分類できることがわかった。 このような崩壊モードの変化は, 他の板厚や防撓材形状で も基本的には同じとなる。

\section{3. 水圧と面内圧縮荷重を受ける連続防撓パネルの 最終強度推定法}

\section{1 最終強度推定法}

\subsection{1 水圧のない場合の最終強度推定法}

以上の解析結果をもとに, 水圧荷重と面内圧縮荷重を受け る連続防撓パネルの最終強度の簡易推定法を提案する。具 体的には，著者らが開発した水圧荷重のない場合の最終強 度推定法 9,10) を，水圧荷重がある場合にも適用できるよ うに拡張する。この最終強度推定法は以下に示す特徵を有 する。

（1）防撓パネルの連続性と隣接スパン間の相互影響を考 慮するため, 連続防撓パネルを隣接スパンにまたがるダブ ルスパン梁・柱モデルに置き換える。

（2） flat-bar 防撓材に対しては，パネルと防撓材の連成 した局部座屈変形による防撓材の軸剛性の低下を，有効板 厚の形で考慮する。

（3）パネルの有効幅と flat-bar 防撓材の有効板厚を，共 に圧縮荷重の関数として表すことにより, 最終強度時点の 有効断面を正確に評価する。

（4）パネル・防撓材間の相互影響として，防撓材の据り 剛性による局部座屈強度の上昇と，防撓材の摸れに対する パネルの抵抗を考虑する。

（5）ダブルスパン梁・柱モデルに複数の降伏判定点を設 定し，これらのいずれか一点で, 軸力, 曲げおよび曲げ据 りによる軸方向応力が, 降伏応力に達したときを最終強度 とする。

すなわち，上述の梁・柱モデルが, Fig. 7 に示すいずれ かの降伏判定点で, 次式で与えられる条件を満足する場合 の圧縮荷重を最終強度とする。

$$
\Gamma=\sigma_{Y}-\left(\sigma_{P}+\sigma_{B}+\sigma_{B T}\right)=0
$$

ここで， $\sigma_{P}$ は圧縮荷重を有効断面で除じた面内応力を表 し， $\sigma_{B}$ は初期たわみを有する梁・柱に圧縮荷重が作用した 場合の曲げ応力を表す。また, $\sigma_{B T}$ は防撓材の曲げ㨝りに よる反り応力を表す。

\section{1 .2 水圧を考虑した最終強度推定法}

2 章で行った FEM 解析結果によれば, 水圧荷重と面内 圧縮荷重を同時に受ける連続防撓パネルの崩壊モードは, SI

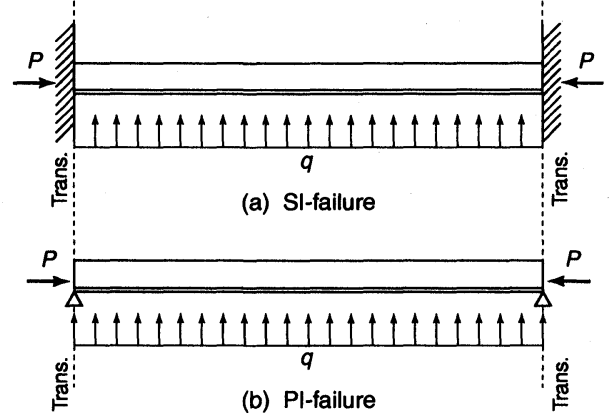

Fig. 8 Assumed boundary conditions to consider influence of lateral pressure

崩壤，PI 崩壊および HI 崩壊の 3 つに分けることができ る。そこで，水圧の影響として，これら 3 つの崩壊モード に対する算式を導出し，それぞれのモードのうち最も小さ な強度を与えるものを真の最終強度とする。

(1) SI 崩壊

比較的水圧荷重が小さい場合，防撓材が曲げの圧縮側と なるスパン中央の防撓材の降伏に起因して圧縮最終強度に 達する。このとき水圧荷重による曲げ応力がこの箇所の降 伏を遅らせるため, 水圧荷重の上昇とともに圧縮最終強度 は上昇する。また，Fig. 5(a) に示した曲げモーメント分布 より, トランス材位置での曲げモーメントは最終強度の時 点でも低下しない。そこで, SI 崩壊では, Fig. 8(a)に示 すような両端固定梁に横荷重と面内圧縮荷重が作用する場 合を考え，この梁のスパン中央での曲げ応力 $\sigma_{B}^{C}$ を式 (2) の $\sigma_{B}$ に加える。 $\sigma_{B}^{C}$ は次式で与えられる。

$$
\begin{aligned}
& \sigma_{B}^{C}=-\frac{q b a^{2}}{24} \cdot \frac{6(\alpha \operatorname{cosec} \alpha-1)}{\alpha^{2}} \cdot \frac{z_{t}}{I_{y}} \\
& \alpha=(\pi / 2) \sqrt{P / P_{c r}}
\end{aligned}
$$

ここで, $P_{c r}$ および $I_{y}$ は $3.1 .1 て ゙$ 述べた有効断面を有す る両端支持梁の曲げ座屈強度および断面 2 次モーメントを 表し， $z_{t}$ は断面の中立位置を原点とした場合の防撓材頂部 の $z$ 座標を表す。この場合，降伏判定は Fig. 7 の F2 あ るいはF3で行う。

(2) PI 崩壤

水圧荷重が比較的大きくなると, パネルが曲げの圧縮側 となるスパン中央でパネルが降伏して，圧縮最終強度に達 する。このとき，トランス材位置では降伏がかなり拡がる。 また, Fig. 5(b) に示したように, この位置での曲げモーメ ントは水圧のみが作用した場合に比べ低下し，スパン端部 の境界条件は，単純支持条件に近づく。そこで, PI 崩壊で は，Fig. 8(b) に示すようなトランス材位置で単純支持さ れた梁・柱に横荷重と面内荷重が作用する場合を考え，こ 


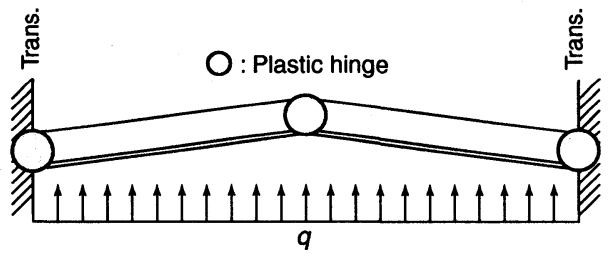

Fig. 9 Collapse mechanism of stiffened plate under only lateral pressure

の梁のスパン中央での曲げ応力 $\sigma_{B}^{S}$ を式 $(2)$ の $\sigma_{B}$ に加え る。 $\sigma_{B}^{S}$ は次式で与えられる。

$$
\sigma_{B}^{S}=-\frac{q b a^{2}}{8} \cdot \frac{2(\sec \alpha-1)}{\alpha^{2}} \cdot \frac{z_{p}}{I_{y}}
$$

$z_{p}$ は断面の中立軸位置を原点とした時のパネル中央面の $z$ 座標を示している。この場合の降伏判定は, Fig. 7 の F5 で行う。

\section{(3) HI 崩壊}

さらに水圧荷重が上昇し, 水圧荷重だけでトランス材位置 に降伏が生じる水圧 $q_{c r}$ を超えると, 最終強度時にはトラ ンス材位置とスパン中央部で塑性関節を形成する崩壊モー ドへと移行し, 圧縮最終強度はほほ線形に隇少していく。水 圧のみが作用する場合にはトランス材位置で固定条件とな ることを考慮すると， $q_{c r}$ は次式で与えられる。

$$
q_{c r}=\frac{12 I_{y}}{a^{2} b z_{t}} \sigma_{Y}
$$

なお上式の $I_{y}$ および $z_{t}$ は全断面が有効として求める。 本研究ではこの $q_{c r}$ を PI 崩壊と HI 崩壊の境界と定め, $q>q_{c r}$ の場合には HI 崩壊が起こるとする。さらに, PI 崩壊のもとで $q=q_{c r}$ のときの圧縮最終強度 $\sigma_{u}^{c r}$ を算出し, この点と剛塑性機構解析で得られる両端固定梁の最大横荷 重 $q_{\max }$ (この時の圧縮最終強度は 0）を直線で結んで近似
する。すなわち, HI 崩壊での圧縮最終強度は次式で与えら れる。

$$
\sigma_{u}=-\frac{\sigma_{u}^{c r}}{q_{\max }-q_{c r}}\left(q-q_{c r}\right)+\sigma_{u}^{c r} \quad q>q_{c r}
$$

ここで, Fig. 9 に示すような 3 点塑性関節が生成される場 合, $q_{\max }$ は次式で与えられる。

$$
q_{\max }=C \frac{16}{a^{2} b} M_{P}
$$

$M_{P}$ は全断面塑性モーメントを表す。剛塑性解析では式 (7) の $C$ は 1 となるが, 実際には防撓材の局部据れ変形の影響 やパネルの局部座屈などの影響により， $C=1$ とはならない 場合が多い。そこで, 本研究では, $C=0.95$ として後の強 度推定を行う。

\section{2 最終強度推定結果}

板厚 $20 \mathrm{~mm}$ のパネルに，比較的防撓材高さの低い type 1 の tee-bar 防撓材が取り付けられた場合の最終強度推定 結果を, 前出の Fig. 3 に示す。図中の実線が SI 崩壊モー ドを仮定した場合を, 点線が PI 崩壊モードを仮定した場 合の推定值を表している。また, 一点鎖線は HI 崩壊での 推定値を表し，○が FEM 解析結果を表している。

Fig. 3 を見ると, 実線で示されている SI 崩壊モードの最 終強度推定值は, 水圧の増加とともに増加していることがわ かる。また，水圧が水頭換算で $5 \mathrm{~m}$ までの範囲では，FEM による最終強度と良く一致している。一方, 点線で示す PI 崩壊の推定值は, 水圧荷重の増加とともに減少し, 水圧が 5 〜 $15 \mathrm{~m}$ の範用で FEM 解析結果とよく一致していることが わかる。ところで, 図中の破線は, 式 (4) に示した両端支 持の曲げ応力に変わって, 両端固定を仮定した曲げ応力を 加えた場合の推定値を表している。破線の結果は FEM 解 析結果に比べ，かなり高めである。このことから，PI 崩壊 モードにおいて，両端支持状態での水圧影響を仮定した本 推定法の妥当性が確認できる。一方, HI 崩壊の推定值は

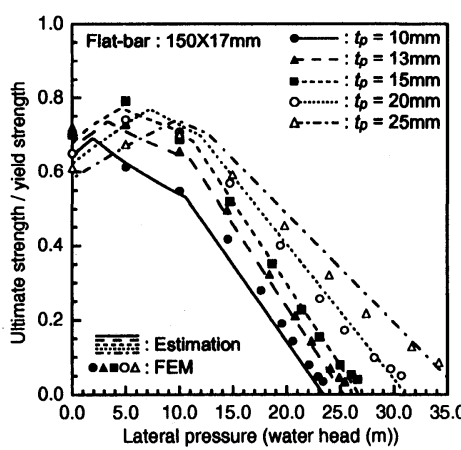

(a) flat-bar, type 1

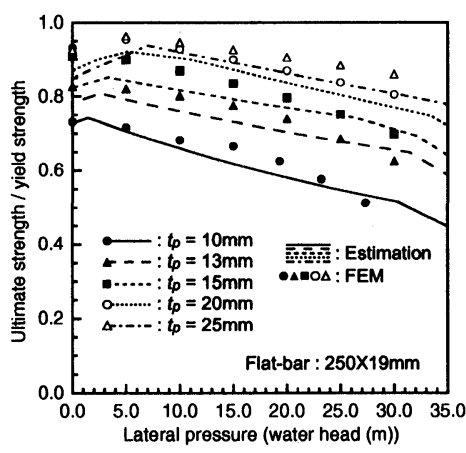

(b) flat-bar, type 2

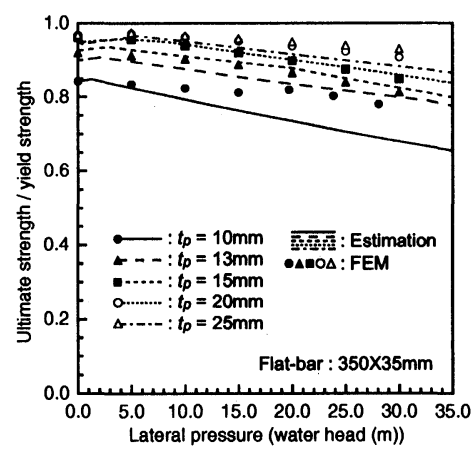

(c) flat-bar, type 3

Fig. 10 Relationships between ultimate strength and lateral pressure obtained by FEM and proposed method 


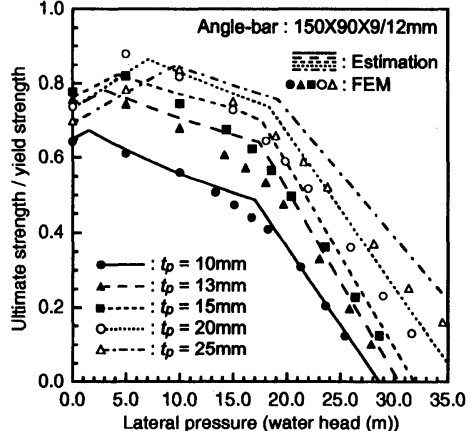

(d) angle-bar, type 1

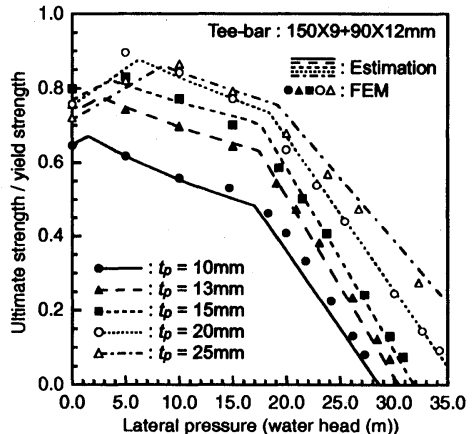

(g) tee-bar, type 1

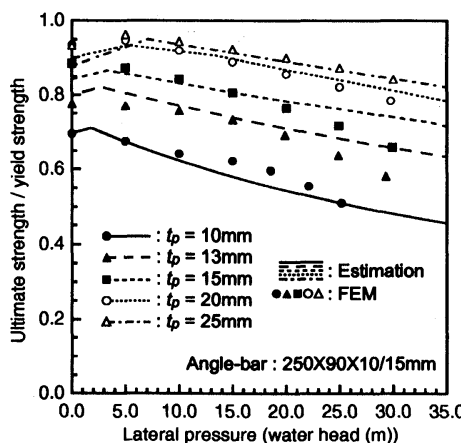

(e) angle-bar, type 2

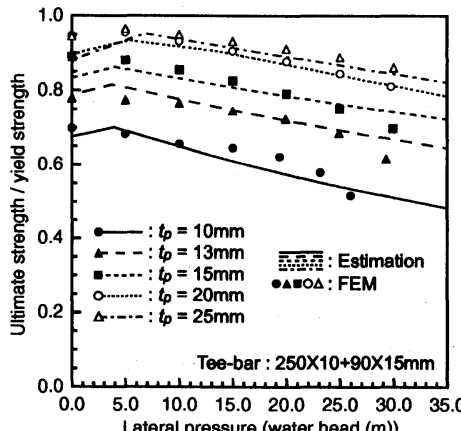

(h) tee-bar, type 2

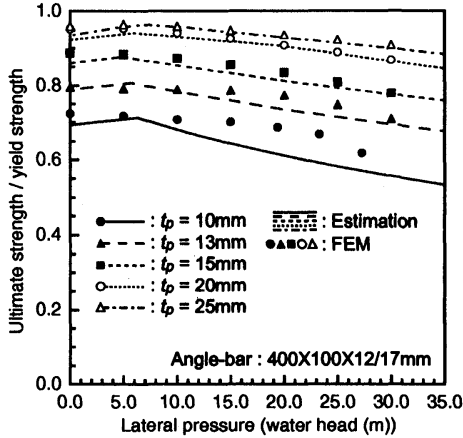

(f) angle-bar, type 3

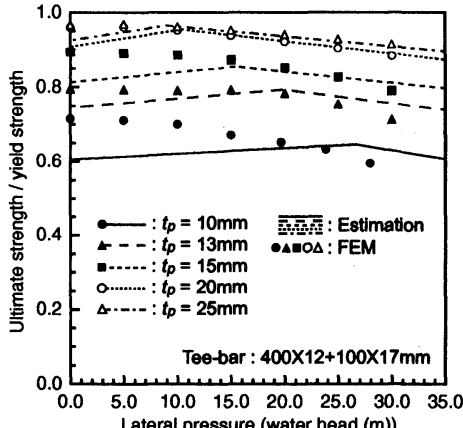

(i) tee-bar, type 3

Fig. 10 Relationships between ultimate strength and lateral pressure obtained by FEM and proposed method (continued)

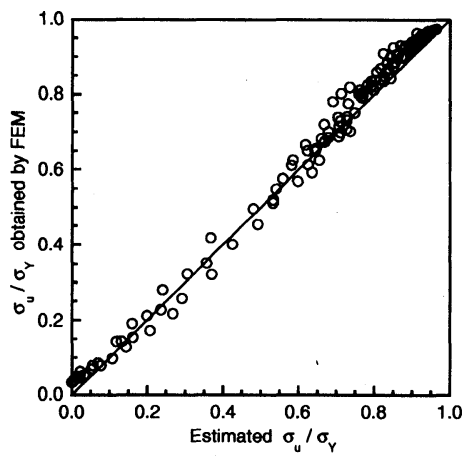

(a) flat-bar

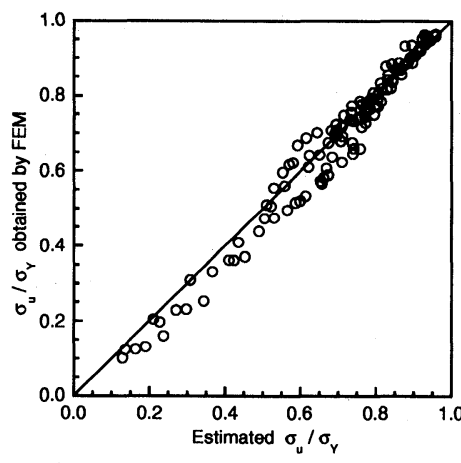

(b) angle-bar

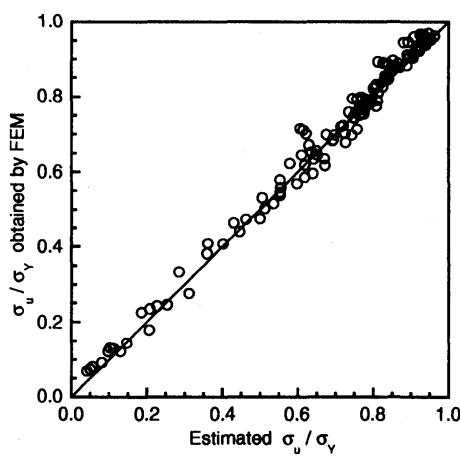

(c) tee-bar

Fig. 11 Comparison between ultimate strength estimated by proposed method and that obtained by FEM

$q>20 \mathrm{~m}$ の範囲で FEM 解析結果とよく一致している。真 の最終強度はこれらのモードのうち最小の推定値を与える ものを選択するので, 本研究で提案した最終強度推定法が 十分な精度を有していることがわかる。

Fig. 10 に解析を行った全てのケースの水圧荷重と圧縮最 終強度の関係を示す。また, Fig.11に flat-bat, angle-bar および tee-bar 防撓材について FEM より得られた圧縮最終 強度と推定値との相間関係を示す。Fig. 10(d) に示す比較
的厚板のパネルに type 1 の angle-bar が取り付けられた 場合では，危険側の推定をしているものがかなり見られる。 これは, 水圧荷重によって生じる曲げ据り応力の影響を考 慮していないためと考えられ，この点は今後改善する予定 である。しかしながら，Fig. 10 および Fig. 11 よりわか るように本推定法による最終強度推定値は FEM 解析結果 と良い相間を有しており，本提案法の妥当性が確認できる。 


\section{4. 結言}

本研究では, 水圧と面内圧縮荷重を受ける連続防撓パネ ルを対象として，FEM による弾塑性大たわみ解析を実施 し, 水圧が防撓パネルの圧壊挙動におよ浔す影響について 考察を行った。その結果, 防撓パネルの崩壊モードは, 水 圧の大きさに応じて, SI 崩壊, PI 崩壊㧍よび HI 崩壊の 3 つに分類できることがわかった。それぞれの崩壊モードの 特徴は以下のとおりである。

（1）SI 崩壊：防撓材が曲げの圧縮側となるスパン中央の 防撓材の降伏に起因して，圧縮最終強度に達する。この場 合, 水圧が作る曲げ応力が防撓材頂部の降伏を遅らせるた め, 水圧の増加に伴い圧縮最終強度は上昇する。また, 圧 縮後もトランス材位置で, 固定条件のもとで水圧が作る曲 げモーメントが保持される。

(2) PI 崩壊：パネルが曲げの圧縮側となるスパン中央の パネルの降伏に起因して, 圧縮最終強度に達する。この場 合, 水圧の増加に伴い圧縮最終強度は低下する。また, 卜 ランス位置で防撓材ははは全断面降伏し, 圧縮荷重が増加 すると,この位置での曲げモーメントは塑性条件に従って 減少する。このため, 最終強度の時点では, トランス材位 置での断面力は単純支持状態に近づく。

（3）HI 崩壊：水圧がさらに大きくなると, 圧縮最終強度 時には，トランス支持部とスパン中央部で塑性関節を形成 する。この場合の圧縮最終強度は, 水圧のみで初期降伏が 生じる横荷重と㣚塑性機構解析より求められる最大横荷重 の間をほほ線形に変化する。

以上の知見に基づき，水圧と面内圧縮荷重を受ける連続 防撓パネルの最終強度推定法を提案した。さらに, FEM 解 析結果と比較を行い, 本提案手法が高い推定精度を有して いることを確認した。

なお本提案手法では，溶接残留応力の考慮がされていな いため, 既存のルール算式や実験結果などとの比較を行っ ていないが, 溶接残留応力を考虑した推定法の開発を行い, これらとの比較を行う予定としている。さらに，近年船体 構造に多用されるようになった極めて背の高い防撓材への 適用性についても検討する予定としている。

\section{参 考 文 献}

1）矢尾哲也, 仁保治, 藤久保昌彦, バル・ベルゲス, 水 谷圭介：船底外板の座屈・塑性崩壊強度に関する研究, 日本造船学会論文集, 第 181 号, 1997, pp.309-321.

2) Yao, T., Fujikubo, M., Varghese, B., Yamamura, K. and Niho, M. : Buckling/Plastic Collapse Strength of Wide Rectangular Plate under Combined Pressure and Thrust, J. Soc. Naval Arch. of Japan, Vol.182, 1997, pp.561-570.

3）藤久保昌彦, 矢尾哲也, Balu Varghese ; 連続防撓パ ネルの局部座屈強度に対する諸因子について, 西部造 船会会報, 第 97 号, 1998, pp.113-123.

4) Fujikubo, M., Yao, T. and Khedmati, M.R. : Estimation of Ultimate Strength of Ship Bottom Plating under Combined Transverse Thrust and Lateral Pressure, J. Soc. Naval Arch. of Japan, Vol.186, 1999, pp.621-630.

5) Fujikubo, M., Yao, T. and Khedmati, M.R. : Estimation of Ultimate Strength of Ship Bottom Plating under Combined Biaxial Thrust and Lateral Pressure, Trans. The West-Japan Soc. Naval Arch., Vol.99, pp.245-254.

6) Smith, C.S. : Compressive Strength of Welded Steel Ship Grillage, Trans. RINA, Vol.117, 1997, pp.325-552.

7) Wang, X. and Moan, T. : Ultimate Strength Analysis of Stiffened Panels in Ships Subjected to Biaxial and Lateral Loading, Int. J. Offshore and Polar Engineering, Vol.7, No.1, 1996, pp.22-29.

8) DNV : Buckling Strength Analysis of Mobile Offshore Units, Classification Notes, No.30.1, 1995.

9）藤久保昌彦, 柳原大輔, 矢尾哲也 : 連続防撓パネルの 圧壊強度の推定法, 日本造船学会論文集, 第 185 号, 1999, pp.203-212.

10）藤久保昌彦, 柳原大輔, 矢尾哲也 : 連続防撓パネルの 圧壊強度の推定法（第 2 報）, 日本造船学会論文集, 第 186 号, 1999, pp.631-638.

11）矢尾哲也, 藤久保昌彦, 柳原大輔, 入沢真生:防撓パネル の座屈・塑性崩壊解析における FEM モデル化に関する 考察，西部造船会会報，第 95 号, 1998, pp.121-128.

12）山田徽志：圧縮および水圧荷重を受ける連続パネルの 座屈・最終強度推定法に関する研究, 広島大学修士論 文, 2001 . 